DOI: https://doi.org/10.36502/2020/hcr.6157

\title{
Mortalities and Morbidities Trends of COVID-19 Infection, From Explosiveness to Aggressiveness, Understanding Gaps in System Response and Transmission Chain Events
}

\author{
Hussain $\mathrm{YH}^{1,2^{*}}$, Baderkhan $\mathrm{B}^{1}$, Hamid $\mathrm{M}^{1}$, Hamid $\mathrm{A}^{1}$
}

${ }^{1}$ Dubai Health Authority, Dubai, United Arab Emirates

${ }^{2}$ Faculty of Medicine, University of Baghdad, Baghdad, Iraq

\section{Corresponding Author: Hamid Yahya Hussain}

Address: Department of Community and Family Medicine, WHO public health Medicine Consultant, POBOX 23317, Sharjah, UAE; Tel: oog71502608873; Email: hussainh569@hotmail.com, hyhussain@dha.gov.ae, Hamid_Hussain57@yahoo.com

Received date: 03 March 2020; Accepted date: 25 March 2020; Published date: 01 April 2020

Citation: Hussain YH, Baderkhan B, Hamid M, Hamid A. Mortalities and Morbidities Trends of COVID-19 Infection, From Explosiveness to Aggressiveness, Understanding Gaps in System Response and Transmission Chain Events. J Health Care and Research. 2020 Apr 01;1(1):22-27.

Copyright (C) 2020 Hussain YH, Baderkhan B, Hamid M, Hamid A. This is an open-access article distributed under the Creative Commons Attribution License, which permits unrestricted use, distribution, and reproduction in any medium, provided the original work is properly cited.

\section{Abstract}

Background: Emerging and reemerging pathogens are global challenges for public health. Coronaviruses are enveloped RNA viruses that are distributed broadly among humans, other mammals, and birds and that cause respiratory, enteric, hepatic, and neurologic diseases. the high prevalence and wide distribution of coronaviruses, the large genetic diversity and frequent recombination of their genomes, and increasing human-animal interface activities, novel coronaviruses are likely to emerge periodically in humans owing to frequent cross-species infections and occasional spillover event.

Objectives: To study the short-term morbidities and mortalities and international spread time trends of the $\mathrm{N}$ Corona Virus 2019 outbreak, to study, to study the explosiveness and aggressiveness of the outbreak and the gaps in response.

Methodology: Outbreak events follow up and observation study over two months has been carried out through daily statistical reports issuing by world health organizations as all as different national authorities regarding (mortalities and morbidities incidents) all over the world with specific focusing on china statistics as main sources of the outbreak. The operational definition of variables regarding case confirmation, case recovery, case admission, and case contacts has been adopted as per WHO definitions. Unofficial statistical reports excluded as a source of data.

Results: The current study showed that the number of cases of N corona-virus 2019 infection, started with (41) cases at the beginning of January 2020 increased up to 855 cases in $23^{\text {rd }}$ January 2020 and 7700 cases of infection in $29^{\text {th }}$ of January 2020 which keep raising and reached up to 78823 by $23^{\text {rd }}$ of February as for mortalities, the current research revealed that the number of death was only (1) case in $4^{\text {th }}$ of Feb 2020 increased up to 25 deaths in $23^{\text {rd }}$ of February 2020 and keep raising reached up to 170 deaths in January $29^{\text {th, }} 2020$ and 2462 death case in $23^{\text {rd }}$ of Feb 2020. In regards of the geographical spread of the N corona-virus 2019 infection outbreak, the study showed that on January $4^{\text {th, }} 2020$ only one country was affected which was china, on $8^{\text {th }}$ of January 2020 two 
Citation: Hussain YH, Baderkhan B, Hamid M, Hamid A. Mortalities and Morbidities Trends of COVID-19 Infection, From Explosiveness to Aggressiveness, Understanding Gaps in System Response and Transmission Chain Events. J Health Care and Research. 2020 Apr 01;1(1):22-27.

countries were affected as Thailand discovered cases, on $13^{\text {th }}$ of January 3 countries were affected by adding Singapore to the list, on Feb $5^{\text {th }} 27$ countries reported incidence of N Corona-virus 2019 infection and reached up to 35 countries by $23^{\text {rd }}$ of February.

Conclusions: The natural history and course of the current outbreak revealed high explosive nature linked to significant aggressiveness in terms of complications and mortalities, within only two months period speeded out to 35 countries worldwide and reached you 80000 incidences within only two months. The study forecasted that the peak of the outbreak is not yet attended and more dramatic events still have high potentials.

\section{Keywords}

COVID-19; N-Corona Virus 2019; Mortality; Morbidity; Explosiveness; Aggisiveness

\section{Introduction}

Emerging and reemerging pathogens are recognized as global public health challenges [1]. Coronaviruses are a kind of RNA enveloped viruses that are broadly distributed among mammals, birds, and humans, and causing acute and severe respiratory infection, hepatic, neurologic and enteric diseases $[2,3]$. Six coronavirus species are known to cause human disease [4]. Four viruses - 229E, OC43, NL63, and HKU1 - are prevalent and typically cause common cold symptoms in immunocompetent individuals [4]. The two other strains - severe acute respiratory syndrome coronavirus (SARS-CoV) and Middle East respiratory syndrome coronavirus (MERS-CoV) - are zoonotic in origin and have been linked to sometimes - fatal illness [5-8]]. In late December 2019, several local health facilities reported clusters of patients with pneumonia of unknown causes that were epidemiologically linked to seafood and wet animal wholesale market in Wuhan, Hubei Province, China. On December 31, 2019, the Chinese Center for Disease Control and Prevention (China $\mathrm{CDC}$ ) dispatched a rapid response team to accompany Hubei provincial and Wuhan city health authorities and to conduct an epidemiologic and etiologic investigation. We report the results of this investigation, identifying the source of the pneumonia clusters, and describe a novel coronavirus detected in patients with pneumonia whose specimens were tested by the China CDC at an early stage of the outbreak. We also describe the clinical features of pneumonia in two of these patients. In December 2019, a series of pneumonia cases of unknown cause emerged in Wuhan, Hubei, China, with clinical presentations greatly resembling viral pneumonia [9]. Deep sequencing analysis from lower respiratory tract samples indicated a novel coronavirus, which was named 2019 novel coronavirus (2019-nCoV). Thus far, more than 800 confirmed cases, including in healthcare workers, have been identified in Wuhan, and several exported cases have been confirmed in other provinces in China, Thailand, Japan, South Korea, and the USA [10-13].

\section{Objectives}

To study the short-term morbidities and mortalities and international spread time trends of the N Corona Virus 2019 outbreak, to study, to study the explosiveness and aggressiveness of the outbreak and the gaps in response.

\section{Methodology}

Outbreak events follow up and observation study over two months has been carried out through daily statistical reports issuing by world health organizations as all as different national authorities regarding (mortalities and morbidities incidents ) all over the world with specific focusing on china statistics as main sources of the outbreak. The operational definition of variables regarding case confirmation, case recovery, case admission, and case contacts has been adopted as per WHO definitions. Unofficial statistical reports excluded as a source of data.

\section{Results}

The current study showed that the number of cases of N corona-virus 2019 infection, started with (41) cases at the beginning of January 2020 increased up to 855 cases in $23^{\text {rd }}$ January 2020 and 7700 cases of infection in $29^{\text {th }}$ of January 2020 which keep raising and reached up to 78823 in $23^{\text {rd }}$ of February as shown 
Citation: Hussain YH, Baderkhan B, Hamid M, Hamid A. Mortalities and Morbidities Trends of COVID-19 Infection, From Explosiveness to Aggressiveness, Understanding Gaps in System Response and Transmission Chain Events. J Health Care and Research. 2020 Apr 01;1(1):22-27.

\section{Original Article}

in the (Fig-1) as for mortalities, the current research revealed that the number of death was only (1) case in $4^{\text {th }}$ of Feb 2020 increased up to 25 death in $23^{\text {rd }}$ of February 2020 and keep raising reached up to 170 deaths in January $29^{\text {th, }} 2020$ and 2462 death case in $23^{\text {rd }}$ of Feb 2020 as reflected by (Fig-2). In regards of the geographical spread of the N Corona-Virus 2019 infection outbreak, the study showed that on January $4^{\text {th, }} 2020$ only one country was affected which was china, on $8^{\text {th }}$ of January 2020 two countries were affected as Thailand discovered cases, on $13^{\text {th }}$ of January 3 countries were affected by adding Singapore to the list, on Feb $5^{\text {th }} 27$ countries reported incidence of $\mathrm{N}$ Corona-Virus 2019 infection and reached up to 35 countries by $23^{\text {rd }}$ of February as reflected by (Fig-3).

\section{Discussions}

The current study revealed a dramatic explosive outbreak of N Corona-virus 2019 infection in terms of several confirmed cases, several deaths and number of countries affected with the outbreak within 50 days, the explosion of the epidemic with high morbidity and mortality incidences reflected another nature of the diseases which is the aggressiveness of the virus. Both the explosiveness and the aggressiveness nature of the

\section{Incidience trend of $\mathbf{n}$-corona virus 2019 infection}

\section{over 2 months period}

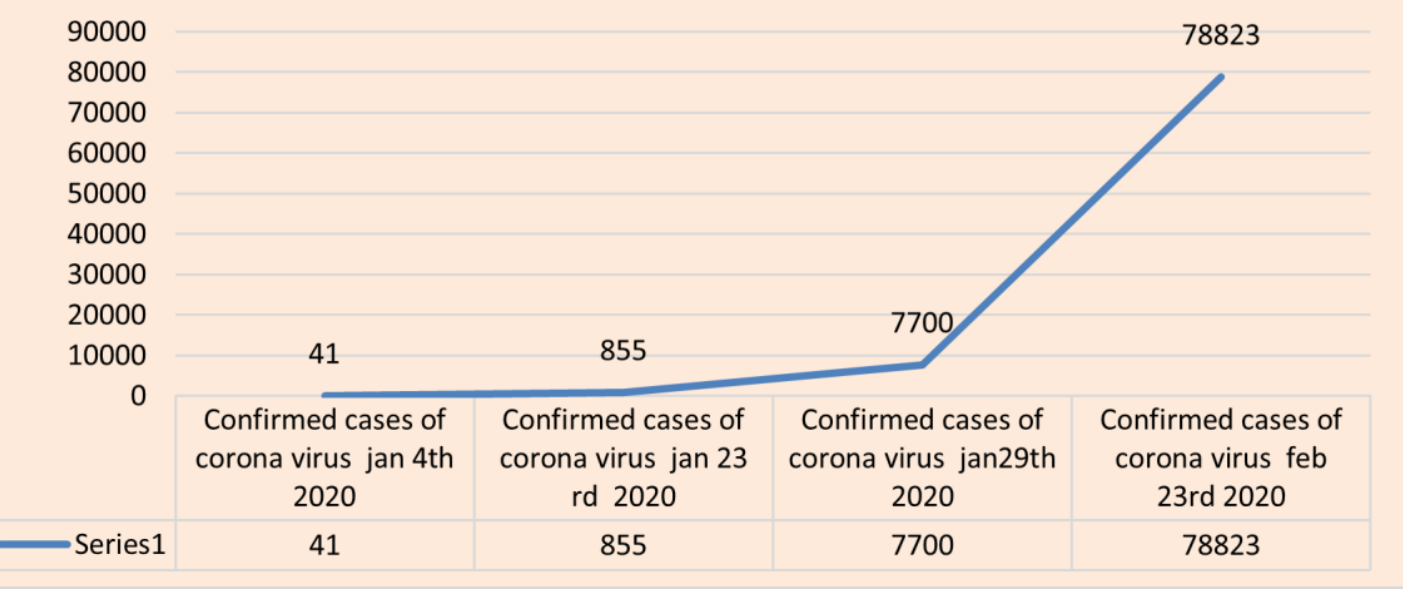

Fig-1: Time trend of corona infection morbidity over two months period

\section{Time trend mortality of $\mathrm{N}$ - corona virus 2019 infection}

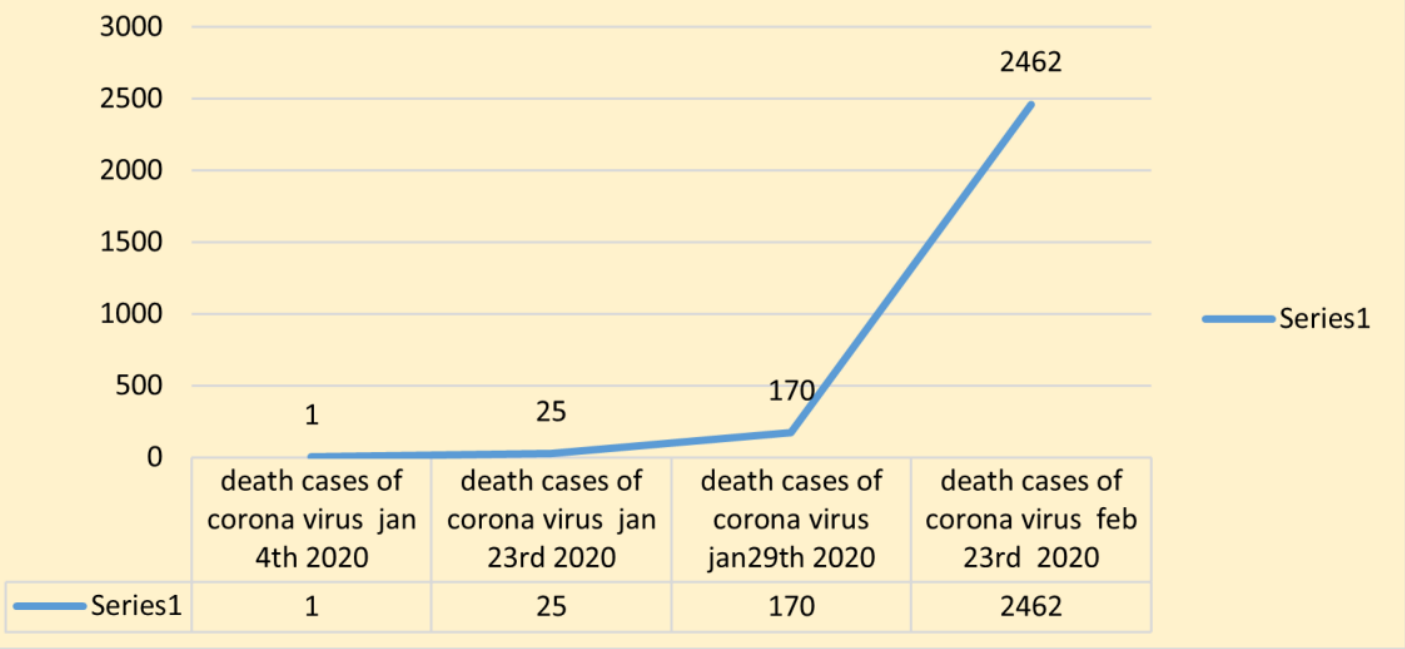

Fig-2: Time trend mortality of N- Corona Virus 2019 infection over two months period 


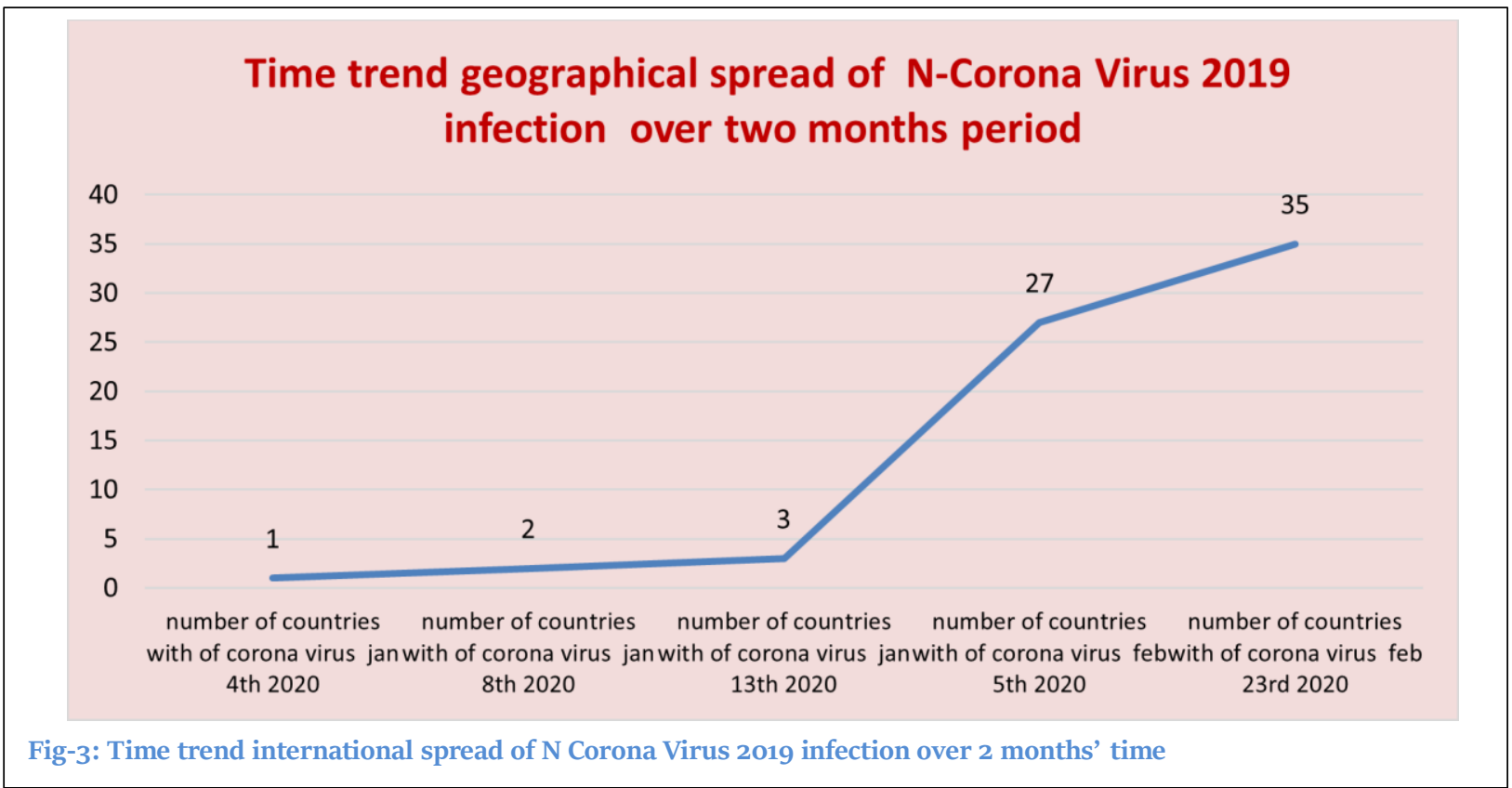

epidemic alarming global as well as national health care systems in regards of responsiveness capacity, containment strategies and applying effective transmission chain break down strategies, the nature of the current epidemic reflected the fragile status of global capacity of health system response along with lack of preparedness and un ability of prediction and forecasting. Furthermore, the current epidemic is taking new trend, moving from localized area to worldwide zones which make containment much harder and needs more efforts at the level of global mobility, which may push toward more economical loss. The other significant observation in the current pandemic is, that we did not reach yet to the peak of the explosion, and there will be further potentials of the epidemic that can be expressed in the coming days and months until it reaches to the peak and decline down.

The symptoms of this novel pneumonia were also non-specific. With patient have other comorbidities had more severe systemic symptoms of generalized weakness and dry cough. As expected, they might have decreased total white blood cell, lymphocyte, or platelet counts, with also extended activated thromboplastin time and increased C-reactive protein level. The multifocal ground-glass changes on lung CT scans were typical of viral pneumonia. Their lung involvement was also more diffuse and extensive than those of the younger patients, whose blood test results were largely normal. The patient, who had a history of chronic sinusitis, might have a bacterial superinfection because he had a productive cough instead of a dry cough. He also had a high white blood cell count, although the bacterial test was negative [1420].

An outbreak of novel coronavirus is ongoing at Wuhan in the winter of 2019-20. Similar to the 2003 SARS outbreak in Guangzhou, Wuhan is also a rapidly flourishing capital city of the Hubei province and the traffic hub of central China. Moreover, both outbreaks were initially connected to wet markets where game animals and meat were sold. In the case of SARS, the person-to-person transmission was efficient and super-spreading events had led to major outbreaks in hotels and hospitals. Learning from the SARS outbreak, which started as animal-to-human transmission during the first phase of the epidemic, all game meat trades should be optimally regulated to terminate this portal of transmission. But as shown in this study, it is still crucial to isolate patients and trace and quarantine contacts as early as possible because asymptomatic infection appears possible (as shown in one of our patients), educate the public on both food and personal hygiene, and alert health-care workers on compliance to infection control to prevent superspreading events. Unlike the 2003 SARS outbreak, the improved surveillance network and laboratory capability of China was able to recognize this outbreak 
Citation: Hussain YH, Baderkhan B, Hamid M, Hamid A. Mortalities and Morbidities Trends of COVID-19 Infection, From Explosiveness to Aggressiveness, Understanding Gaps in System Response and Transmission Chain Events. J Health Care and Research. 2020 Apr 01;1(1):22-27.

within a few weeks and announced the virus genome sequences that would allow the development of rapid diagnostic tests and efficient epidemiological control. Our study showed that person-to-person transmission in family homes or hospitals, and intercity spread of this novel coronavirus are possible and therefore vigilant control measures are warranted at this early stage of the epidemic [20-25].

\section{Conclusions}

The natural history and course of the current outbreak revealed high explosive nature linked to significant aggressiveness in terms of complications and mortalities, within only two months period speeded out to 35 countries worldwide and reached you 80000 incidences within two months only. The study forecasted that the peak of the outbreak is not yet attended and more dramatic events still have high potentials of further enormous damages worldwide.

\section{Recommendations}

Rigorous international as well as national public health measures and clinical measures at population, contacts, cases, need to be strictly secured, breaking down transmission chain at all its events shall be the most effective strategy that can be applied ever.

\section{Ethical issue}

All ethical issues have been applied as per standards.

\section{Conflict of interest}

All authors declared that there are no conflicts of interests.

\section{References}

[1] Richman DD, Whitley RJ, Hayden FG, editors. Clinical virology. John Wiley \& Sons; 2016 Dec 1.

[2] Ksiazek TG, Erdman D, Goldsmith CS, Zaki SR, Peret T, Emery S, Tong S, Urbani C, Comer JA, Lim W, Rollin PE, Dowell SF, Ling AE, Humphrey CD, Shieh WJ, Guarner J, Paddock CD, Rota P, Fields B, DeRisi J, Yang JY, Cox N, Hughes JM, LeDuc JW, Bellini WJ, Anderson LJ; SARS Working Group. A novel coronavirus associated with severe acute respiratory syndrome. N Engl J Med. 2003 May
15;348(20):1953-66. [PMID: 1269oog2]

[3] Kuiken T, Fouchier RA, Schutten M, Rimmelzwaan GF, van Amerongen G, van Riel D, Laman JD, de Jong T, van Doornum G, Lim W, Ling AE, Chan PK, Tam JS, Zambon MC, Gopal R, Drosten C, van der Werf S, Escriou N, Manuguerra JC, Stöhr K, Peiris JS, Osterhaus AD. Newly discovered coronavirus as the primary cause of severe acute respiratory syndrome. Lancet. 2003 Jul 26;362(9380):263-70. [PMID: 12892955]

[4] Drosten C, Günther S, Preiser W, van der Werf S, Brodt HR, Becker S, Rabenau H, Panning M, Kolesnikova L, Fouchier RA, Berger A, Burguière AM, Cinatl J, Eickmann M, Escriou N, Grywna K, Kramme S, Manuguerra JC, Müller S, Rickerts V, Stürmer M, Vieth S, Klenk HD, Osterhaus AD, Schmitz H, Doerr HW. Identification of a novel coronavirus in patients with severe acute respiratory syndrome. N Engl J Med. 2003 May 15;348(20):1967-76. [PMID: 1269oog1]

[5] de Groot RJ, Baker SC, Baric RS, Brown CS, Drosten C, Enjuanes L, Fouchier RA, Galiano M, Gorbalenya AE, Memish ZA, Perlman S, Poon LL, Snijder EJ, Stephens GM, Woo PC, Zaki AM, Zambon M, Ziebuhr J. Middle East respiratory syndrome coronavirus (MERS-CoV): announcement of the Coronavirus Study Group. J Virol. 2013 Jul;87(14):7790-92. [PMID: 23678167]

[6] Zaki AM, van Boheemen S, Bestebroer TM, Osterhaus $\mathrm{AD}$, Fouchier RA. Isolation of a novel coronavirus from a man with pneumonia in Saudi Arabia. N Engl J Med. 2012 Nov 8;367(19):1814-20. [PMID: 23075143]

[7] WHO. Summary of probable SARS cases with onset of illness from 1 November 2002 to 31 July 2003.Accessed: 19 Jan 2020.

https://www.who.int/csr/sars/country/table2004_04 -21/en/

[8] WHO. Middle East respiratory syndrome coronavirus (MERS-CoV). Accessed: 19 Jan 2020. http://www.who.int/emergencies/mers-cov/en/

[9] WHO. Novel coronavirus - China. Accessed: 19 Jan 2020. http://www.who.int/csr/don/12-january-2020novel-coronavirus-china/en/

[10] WHO. Novel coronavirus - Thailand (ex-China). Accessed: 19 Jan 2020.

http://www.who.int/csr/don/14-january-2020-novelcoronavirus-thailand/en/ 
Citation: Hussain YH, Baderkhan B, Hamid M, Hamid A. Mortalities and Morbidities Trends of COVID-19 Infection, From Explosiveness to Aggressiveness, Understanding Gaps in System Response and Transmission Chain Events. J Health Care and Research. 2020 Apr 01;1(1):22-27.

[11] WHO. Novel coronavirus - Japan (ex-China). Accessed: 19 Jan 2020.

http://www.who.int/csr/don/17-january-2020novel-coronavirus-japan-ex-china/en/

[12] WHO. Novel coronavirus - Republic of Korea (ex-China). Accessed: 23 Jan 2020.

http://www.who.int/csr/don/21-january-2020novel-coronavirus-republic-of-korea-ex-china/en/

[13] CDC. First travel-related case of 2019 novel coronavirus detected in United States. Accessed: 23 Jan 2020.

https://www.cdc.gov/media/releases/2020/po121novel-coronavirus-travel-case.html

[14] Tan W, Zhao X, Ma X, Wang W, Niu P, Xu W, Gao GF, Wu GZ. A novel coronavirus genome identified in a cluster of pneumonia cases-Wuhan, China 20192020. China CDC Weekly. 2020 Jan;2(4):61-62.

[15] Centre for Health Protection of the Hong Kong Special Administrative Region Government. CHP closely monitors cluster of pneumonia cases on Mainland. Accessed: 21 Jan 2020.

https://www.info.gov.hk/gia/general/201912/31/P20 19123100667.html

[16] Centre for Health Protection of the Hong Kong Special Administrative Region Government. CHP provides further information on cluster of pneumonia cases in Wuhan. Accessed: 21 Jan 2020.

https://www.info.gov.hk/gia/general/202001/12/P2O 20011200710.html

[17] D Juan. Wuhan wet market closes amid pneumonia outbreak, China Daily. Accessed: 21 Jan 2020.

https://www.chinadaily.com.cn/a/202001/o1/WS5eo c6a49a310cf3e35581e3o.html

[18] Cohen J. Chinese researchers reveal draft genome of virus implicated in Wuhan pneumonia outbreak. American Association for the Advancement of Science, Washington, DC. Accessed: 21 Jan 2020. https://www.sciencemag.org/news/2020/01/chinese -researchers-reveal-draft-genome-virus-implicatedwuhan-pneumonia-outbreak

[19] To KK, Chan KH, Li IW, Tsang TY, Tse H, Chan JF, Hung IF, Lai ST, Leung CW, Kwan YW, Lau YL. Viral load in patients infected with pandemic H1N1 2009 influenza A virus. Journal of medical virology. 2010 Jan;82(1):1-7.

[20] To KKW, Yip CCY, Lai CYW, Wong CKH, Ho
DTY, Pang PKP, Ng ACK, Leung KH, Poon RWS, Chan $\mathrm{KH}$, Cheng VCC, Hung IFN, Yuen KY. Saliva as a diagnostic specimen for testing respiratory virus by a point-of-care molecular assay: a diagnostic validity study. Clin Microbiol Infect. 2019 Mar;25(3):372-78. [PMID: 29906597]

[21] Chan KH, To KKW, Li PTW, Wong TL, Zhang R, Chik KKH, Chan G, Yip CCY, Chen HL, Hung IFN, Chan JFW, Yuen KY. Evaluation of NxTAG Respiratory Pathogen Panel and Comparison with xTAG Respiratory Viral Panel Fast v2 and Film Array Respiratory Panel for Detecting Respiratory Pathogens in Nasopharyngeal Aspirates and Swine/Avian-Origin Influenza A Subtypes in Culture Isolates. Adv Virol. 2017;2017:1324276. [PMID: 28947901]

[22] Peiris JS, Lai ST, Poon LL, Guan Y, Yam LY, Lim W, Nicholls J, Yee WK, Yan WW, Cheung MT, Cheng VC, Chan KH, Tsang DN, Yung RW, Ng TK, Yuen KY; SARS study group. Coronavirus as a possible cause of severe acute respiratory syndrome. Lancet. 2003 Apr 19;361(9366):1319-25. [PMID: 12711465]

[23] Chan JF, Zhang AJ, Chan CC, Yip CC, Mak WW, Zhu H, Poon VK, Tee KM, Zhu Z, Cai JP, Tsang JO, Chik KK, Yin F, Chan KH, Kok KH, Jin DY, Au-Yeung RK, Yuen KY. Zika Virus Infection in Dexamethasoneimmunosuppressed Mice Demonstrating Disseminated Infection with Multi-organ Involvement Including Orchitis Effectively Treated by Recombinant Type I Interferons. EBioMedicine. 2016 Dec;14:112-22. [PMID: 27884655]

[24] To KKW, Chan WM, Li KSM, Lam CSF, Chen Z, Tse H, Lau SKP, Woo PCY, Yuen KY. High prevalence of four novel astrovirus genotype species identified from rodents in China. J Gen Virol. 2017 May;98(5):1004-15. [PMID: 28537544]

[25] Woo PC, Lau SK, Teng JL, Tsang AK, Joseph M, Wong EY, Tang Y, Sivakumar S, Bai R, Wernery R, Wernery U, Yuen KY. Metagenomic analysis of viromes of dromedary camel fecal samples reveals large number and high diversity of circoviruses and picobirnaviruses. Virology. 2014 Dec;471-473:117-25. [PMID: 25461537]

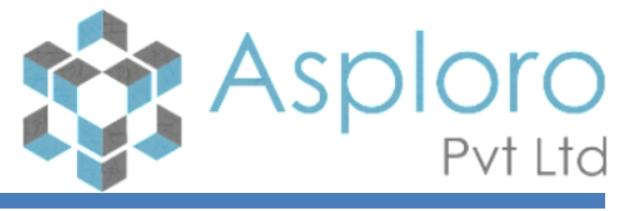

